Rebecca A. Lange $\cdot$ Katharine V. Cashman

Alexandra Navrotsky

\title{
Direct measurements of latent heat during crystallization and melting of a ugandite and an olivine basalt
}

Received: 19 October 1993 / Accepted: 3 May 1994

\begin{abstract}
Step-scanning calorimetric measurements using a Setaram HT1500 calorimeter were performed between 800 and $1400^{\circ} \mathrm{C}$ on two natural samples: a ugandite from the East African rift and an olivine basalt from the western Mexican arc. Our measurements provide the first in-situ quantitative assessment of enthalpy during melting of initially crystalline natural samples. The distribution of latent heat across the liquidus-solidus intervals of the two samples is distinctly different, reflecting significant variation in the sequence and abundance of mineral phases during melting (clinopyroxene and leucite in the ugandite; olivine, clinopyroxene, and plagioclase in the basalt). Our data further indicate that the common assumption of a uniform distribution of latent heat across the liquidus-solidus interval of a mag$\mathrm{ma}$ is a reasonable approximation for the olivine basalt, but is grossly in error for the ugandite. This is due to cotectic precipitation of leucite and clinopyroxene, leading to a large, disproportionate release of latent heat early in the crystallization sequence. The implication for the thermal history of a crystallizing ugandite magma is that the rate of heat loss during conductive cooling will initially be more rapid than the average rate. The net result will be to produce lower magmatic temperatures after a given cooling interval relative to models assuming a uniform release of latent heat. An additional series of scanning calorimetric experiments were performed at variable rates $(1,2$, and $3 \% / \mathrm{min})$ to evaluate the role of kinetics on the distribution of enthalpy during both melting and crystallization of the ugandite and olivine
\end{abstract}

R.A. Lange ( $\square)$

Department of Geological Sciences, University of Michigan, Ann Arbor, MI 48109, USA

K.V. Cashman

Department of Geological Sciences, University of Oregon, Eugene, OR 97403, USA

A. Navrotsky

Department of Geological and Geophysical Sciences,

Princeton University, Princeton, NJ 08544, USA

Editorial responsibility: T.L. Grove basalt. The results indicate that clinopyroxene is the most important mineral phase in controlling the shapes of the enthalpy profiles during cooling; this is due to its large enthalpy of fusion and its tendency for sluggish nucleation, followed by rapid crystallization at temperatures that vary with cooling rate. The resolution of the calorimeter (in terms of heat detected per unit time) is also important in determining the shapes of the observed enthalpy profiles during these rapid scans. Estimates based on the observed calorimetric signal associated with melting of olivine, and the lack of a calorimetric signal during melting of leucite, combined with known enthalpies of fusion for the two phases, indicate detection limits of approximately $0.6-1.2 \mathrm{~kJ}$ per $5 \mathrm{~min}$ increments.

\section{Introduction}

The contribution of latent heat to the thermal evolution of crystallizing magma bodies has been the subject of numerous studies (Lovering 1936; Larsen 1945; Jaeger 1959, 1961; Brandeis et al. 1984; Spohn et al. 1988; Delaney 1988; DeYoreo et al. 1989; Ghiorso 1991; Cashman 1993). In general, the thermal history of a cooling magma body is controlled by a balance between the rate of heat loss to the surrounding country rocks, the heat capacity of the partially molten region, and the production of latent heat associated with crystallization. A significant uncertainty in modelling heat transfer in crystallizing magma bodies arises from deciding how best to model the latent heat term; it enters the differential equation of heat flow as a source term (Carslaw and Jaeger 1959), and therefore must be known a priori as a function of both distance and time.

Solution to this problem has generally involved one of two assumptions: (a) latent heat is released from a magma at a single crystallization temperature, or (b) the total amount of heat released is averaged uniformly over the crystallization interval. The first assumption is wrong, and the second is an over-simplification. Not 
only does crystallization in a magma proceed over a large liquidus-solidus interval (typically $250-350^{\circ} \mathrm{C}$ ), but the sequence of crystallization can also vary dramatically between magma types, leading to a non-uniform liberation of latent heat that is unique for each magma. For example, when and if the crystallization path of a magma reaches a two- or three-phase cotectic, there will be a disproportionately large release of heat relative to a comparable cooling interval where only one phase is crystallizing. This effect has been quantitatively demonstrated by Ghiorso (1991) using a thermodynamic solution model (Ghiorso et al. 1983) to calculate the equilibrium crystallization path and enthalpy release for two different magma types: a tholeiite and a boninite. In that study, it was shown that the heat outputs accompanying equilibrium crystallization of the two magma types are quite distinct and are not uniform functions of magmatic temperature.

Documenting enthalpy variations across the liquidus-solidus interval is important not only for studies of crystallization, but also for studies of melt generation in both crustal and mantle source regions. For example, DeYoreo et al. (1989) suggested that the volume of crustal melt produced following a tectonic thickening event can vary by more than a factor of two when the distribution of latent heat over the melting range is changed from linear to quadratic.

Currently, all our information on the release (or absorption) of enthalpy in crystallizing (or melting) magmatic systems is derived from heat of fusion measurements on various pure, end-member mineral components (e.g., $\mathrm{CaMgSi}_{2} \mathrm{O}_{6}, \quad \mathrm{NaAlSi}_{3} \mathrm{O}_{8}, \mathrm{NaAlSiO}_{4}$, $\mathrm{CaAl}_{2} \mathrm{Si}_{2} \mathrm{O}_{8}, \mathrm{CaSiO}_{3}, \mathrm{Mg}_{3} \mathrm{Al}_{2} \mathrm{Si}_{3} \mathrm{O}_{12}$; Stebbins et al. 1983; Richet and Bottinga 1984). In this paper, we provide the first direct measurements of enthalpy during both melting and crystallization in a natural multicomponent system, specifically a ugandite and an olivine basalt. Our measurements were obtained using a Setaram HT1500 calorimeter in step-scanning mode (Lange and Navrotsky 1992); this approach involves measuring the change in enthalpy of a sample during heating (or cooling) over a small temperature interval $\left(10^{\circ} \mathrm{C}\right)$. Two types of experiments are reported: (a) quantitative measurements of "apparent" heat capacity during melting of initially crystalline samples of a ugandite and an olivine basalt, and (b) qualitative enthalpy profiles during both melting and crystallization of a ugandite and an olivine basalt over a range of cooling and heating rates. The latter experiments are used to evaluate the effect of both composition and kinetics on the non-uniform distribution of enthalpy across the liquidus-solidus interval.

\section{Experimental methods}

Two samples were chosen for this investigation, an olivine basalt (LV-134, western Mexican volcanic arc; Carmichael et al. unpublished work) and a ugandite (U-150, east African rift, western Uganda; Brown 1971); their compositions are presented in Table
Table 1 Electron microprobe analyses (wt \%) of quenched glassy samples

\begin{tabular}{lcc}
\hline Sample: & Ugandite & Olivine Basalt \\
\hline $\mathrm{SiO}_{2}$ & 40.24 & 48.83 \\
$\mathrm{TiO}_{2}$ & 4.83 & 1.19 \\
$\mathrm{Al}_{2} \mathrm{O}_{3}$ & 8.24 & 12.04 \\
$\mathrm{Fe}_{2} \mathrm{O}_{3}$ & 9.51 & 5.77 \\
$\mathrm{FeO}$ & 2.90 & 2.51 \\
$\mathrm{MnO}$ & 0.22 & 0.18 \\
$\mathrm{MgO}$ & 9.72 & 16.69 \\
$\mathrm{CaO}$ & 14.26 & 7.36 \\
$\mathrm{Na}_{2} \mathrm{O}$ & 1.18 & 2.42 \\
$\mathrm{~K}_{2} \mathrm{O}$ & 6.57 & 1.93 \\
$\mathrm{P}_{2} \mathrm{O}_{5}$ & 1.52 & 0.54 \\
Total & 99.19 & 99.46 \\
\hline
\end{tabular}

${ }^{a}$ Ferric-ferrous ratio calculated from Kilinc et al. (1983) assuming equilibrium in air at $1400^{\circ} \mathrm{C}$

1. These samples were chosen because they have low viscosities, which reduces problems with kinetic delays in melting and crystallization. Moreover, each rock is characterized by a completely different phenocryst assemblage; clinopyroxene and leucite are the dominant phases in the ugandite, whereas olivine, clinopyroxene, and feldspar occur in the olivine basalt.

Before calorimetry, each sample was pre-loaded into a $95 \%$ $\mathrm{Pt}-5 \%$ Au capsule and fused overnight in a box furnace in air above its liquidus. The capsule was then cleaned with HF and a fresh batch of sample was re-loaded into the same Pt-Au capsule. This presaturation procedure, combined with the fact that the calorimetric measurements were performed in air, minimized iron loss from the sample to the capsule.

Calorimetric measurements were made with a Setaram HT1500 calorimeter in both step-scanning mode (for quantitative measurements of apparent heat capacity) and scanning mode (for qualitative "instantaneous" enthalpy profiles). Because the apparatus and experimental procedure have been described in detail by Lange et al. (1991) and Lange and Navrotsky (1992), only a brief summary is presented here. The calorimetric detector consists of an upper and lower thermopile surrounding a sample and reference chamber respectively. Approximately $1 \mathrm{~g}$ of sample was held in a $95 \% \mathrm{Pt}-5 \%$ Au crucible that was contained within the sample chamber in air. During a step-scanning run, the thermopile voltage was monitored as the temperature was raised at a rate of $1^{\circ} \mathrm{C} / \mathrm{min}$ over $10^{\circ} \mathrm{C}$. A $10 \mathrm{~min}$ heating period was followed by a $15 \mathrm{~min}$ isothermal interval to allow thermal equilibration (and the voltage to return to baseline). A typical run consisted of ten heating steps. The integrated area under each voltage peak represents one datum point. A single, step-scanning experiment consisted of three runs: a blank (empty Pt crucible), a calibration (corundum powder), and a sample. The results of the blank were subtracted from those of the calibration and sample runs, and the corundum $C_{p}$ data of Robie et al. (1978) were used to derive $C_{p}$ values for the samples. A detailed discussion of the precision and accuracy of these experiments is found in Lange and Navrotsky (1992). The standard deviations on the average integrated areas for the blank, calibration, and sample runs lead to a propagated error on $\mathrm{C}_{\mathrm{p}}$ (sample) of $5-10 \%$.

Experiments were also conducted in scanning mode. In this approach, the voltage difference between the sample and reference thermopiles was monitored as a sample was cooled (crystallized) or heated (melted) at a constant rate (one, two, and three ${ }^{\circ} \mathrm{C} / \mathrm{min}$ in different experiments). The calorimetric signal recorded across the liquidus-solidus interval of each sample is directly proportional to the instantaneous enthalpy release or absorption during crystallization and melting, respectively.

Cooling and heating quench experiments. Simulations of each calorimetric experiment were performed in a quench vertical tube 
furnace. Samples were run through the same thermal history as experienced in the calorimeter, and quenched at various temperatures corresponding to "key" regions observed in the calorimetric experiments. This was necessary because actual calorimetric runs cannot be quenched but cool over several hours before disassembly. The quenched samples were cut in half and mounted in epoxy for electron microprobe analyses and back-scattered electron (BSE) images. Analyses of the quenched charges were performed using a Cameca Camebax electron microprobe; standard operating conditions consisted of a focused electron beam, an accelerating current of $15 \mathrm{kV}$, and a sample current of $10 \mathrm{nA}$. Backscattered electron images were obtained with a Hitachi S-570 scanning electron microscope at the University of Michigan and a JEOL 6300 scanning electron microscope at the University of Oregon. Measurement of sample modes was performed by digital image analysis of BSE images using Dapple "Prism" software. On samples where the gray scale contrast of individual phases was insufficient to differentiate between them, modes were measured based on single x-ray element maps; discrimination of phases was performed using Link software.

\section{In-situ measurements of latent heat during melting}

Quantitative measurements of "apparent" heat capacity (the absorption of latent heat over $10^{\circ} \mathrm{C}$ increments):

$\frac{\mathrm{H}_{\mathrm{T}+\Delta \mathrm{T}}-\mathrm{H}_{\mathrm{T}}}{\Delta \mathrm{T}}=\mathrm{C}_{\mathrm{p}}^{\text {apparent }}=\frac{\Delta \mathrm{H}_{\text {fusion }}}{\Delta \mathrm{T}}+\mathrm{C}_{\mathrm{p}}$

were made during melting of the initially crystalline ugandite sample and olivine basalt sample. The powdered rocks were initially taken to temperatures above their liquidi $\left(1300^{\circ} \mathrm{C}\right.$ and $1400^{\circ} \mathrm{C}$ respectively), then cooled slowly $\left(5^{\circ} / \mathrm{h}\right)$ to $800^{\circ} \mathrm{C}$, and held there for $24 \mathrm{~h}$ prior to the first calorimetric step-scanning run. The same heating and cooling sequences were also performed on each rock in a vertical tube quench furnace; samples were quenched at $800^{\circ} \mathrm{C}$ in order to determine their modes at the beginning of their respective melting calorimetric runs.

\section{Ugandite}

The fully crystalline ugandite sample has a modal composition of approximately $25 \%$ leucite, $45 \%$ clinopyroxene, $16 \%$ titanomagnetite, $7 \%$ perovksite, $4 \%$ nepheline, and $3 \%$ olivine at $800^{\circ} \mathrm{C}$. Calorimetric measurements were collected between 818 and $1378^{\circ} \mathrm{C}$; heat capacities (based on the change in enthalpy over each $10^{\circ} \mathrm{C}$ interval) are reported in Table 2 and Fig. 1 . The most striking feature is the abrupt rise in heat capacity that begins at approximately $1050^{\circ} \mathrm{C}$, peaks at $1200^{\circ} \mathrm{C}$, and then falls to a relatively constant value at $\sim 1250^{\circ} \mathrm{C}$. Simulation melting experiments in a quench furnace indicate that at $1050^{\circ} \mathrm{C}$ there is $\sim 20 \%$ melt, and leucite, clinopyroxene, olivine, and spinel are the only remaining phases. Resorption textures further show that the abrupt rise in heat capacity at $\sim 1050^{\circ} \mathrm{C}$ corresponds to the onset of melting of clinopyroxene; this is followed by significant melting of leucite by $\sim 1160^{\circ} \mathrm{C}$. Clinopyroxene is completely melted by $1220^{\circ} \mathrm{C}$, leucite is gone by

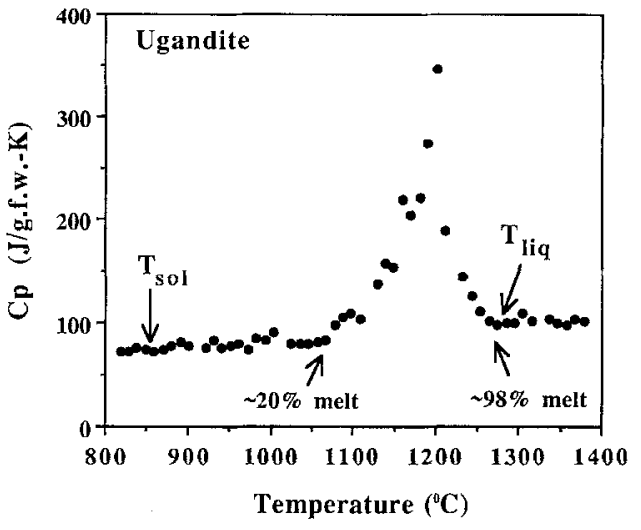

Fig. 1 Plot of measured heat capacity vs temperature during melting of the ugandite. $\mathrm{T}_{\text {sol }}$ and $\mathrm{T}_{\text {liq }}$ refer to the solidus and liquidus temperaures respectively

$1250^{\circ} \mathrm{C}$, and olivine and titanomagnetite persist until $1267^{\circ} \mathrm{C}$. The small peak at $\sim 1310^{\circ} \mathrm{C}$ appears to be an artifact (reflecting the scatter in the data at high temperature) since quenched melting runs have only pure glass between 1270 and $1310^{\circ} \mathrm{C}$.

Figure 1 shows that the $C_{p}$ curve can resolve the liquidus temperature of the ugandite sample, although definition of the solidus is less clear. This is because the melt fraction across the liquidus-solidus curve is not linear. For example, only $\sim 20 \%$ of the rock melts during the first $200^{\circ} \mathrm{C}$ of the solidus-liquidus interval $(850$ $1050^{\circ} \mathrm{C}$ ), whereas more than $75 \%$ melts over the next $200^{\circ} \mathrm{C}\left(1050-1250^{\circ} \mathrm{C}\right)$. The region close to the liquidus is, therefore, much more readily resolved than the solidus by calorimetry.

The distribution of enthalpy across the liquidussolidus interval was calculated by integration of the heat capacity curve in Fig. 1 using the following relationship:

$\mathrm{H}_{\mathrm{T}}-\mathrm{H}_{\mathrm{Ti}}=\int_{\mathrm{Ti}}^{\mathrm{T}} \mathrm{C}_{\mathrm{p}}(\mathrm{T}) \mathrm{dT}$

where $T_{i}$ is the initial temperature of measurement and $T$ is the experimental temperature. Area integration was performed by cubic interpolation of the data points with the stipulation that at $1200^{\circ} \mathrm{C}$, the $\mathrm{C}_{\mathrm{p}}$ reaches a maximum. Although the enthalpy of the crystalline sample at $\mathrm{T}_{\mathrm{i}}\left(807^{\circ} \mathrm{C}\right)$ relative to its standard state enthalpy at $25^{\circ} \mathrm{C}$ is not known (i.e., $\mathrm{H}_{807}-\mathrm{H}_{25^{\circ} \mathrm{C}}$ ), the difference in relative enthalpy between the solidus and liquidus temperatures can be readily computed. Values of $\mathrm{H}_{\mathrm{T}}-\mathrm{H}_{\mathrm{Ti}}$ for the ugandite sample are listed in Table 2. The total enthalpy of fusion is $49 \mathrm{~kJ} / \mathrm{gfw}^{1}$ for the multiphase rock.

\section{Olivine basalt}

The distribution of latent heat during melting of the olivine basalt sample is distinctly different from that for

\footnotetext{
${ }^{1} \mathrm{gfw}=$ gram fromula weight $=\Sigma \mathrm{X}_{\mathrm{i}} \mathrm{MW}_{\mathrm{i}}$, where $\mathrm{X}_{\mathrm{i}}$ is the mole fraction of each oxide component and $\mathrm{MW}_{\mathrm{i}}$ is the molecular weight of each oxide component
} 
Table 2 Ugandite heat capacity and enthalpy data

\begin{tabular}{|c|c|c|c|c|c|c|}
\hline $\begin{array}{l}\text { Temp } \\
\mathrm{K}\end{array}$ & $\begin{array}{l}\mathrm{Cp} \\
\mathrm{J} / \mathrm{gfw}-\mathrm{K} \\
\text { (meas) }\end{array}$ & $\begin{array}{l}\mathrm{Cp} \\
\mathrm{J} / \mathrm{gfw}-\mathrm{K} \\
\text { (calc) }^{\mathrm{a}}\end{array}$ & $\begin{array}{l}\Delta \\
\mathrm{J} / \mathrm{gfw}-\mathrm{K}\end{array}$ & $\begin{array}{l}\mathrm{H}_{\mathrm{T}}-\mathrm{H}_{\mathrm{Ts}} \\
\mathrm{kJ} / \mathrm{gfw} \\
\text { (meas) }\end{array}$ & $\begin{array}{l}\mathrm{H}_{\mathrm{T}}-\mathrm{H}_{\mathrm{Ts}} \\
\mathrm{kJ} / \mathrm{gfW} \\
(\mathrm{calc})^{\mathrm{a}}\end{array}$ & $\begin{array}{l}\Delta \\
\mathrm{kJ} / \mathrm{gfw}\end{array}$ \\
\hline 807 & & & & 0 & 0 & 0 \\
\hline 818 & 72.7 & 72.7 & 0 & 0.8 & 0.8 & 0 \\
\hline 828 & 72.5 & 72.5 & 0 & 1.5 & 1.5 & 0 \\
\hline 838 & 75.5 & 75.5 & 0 & 2.3 & 2.3 & 0 \\
\hline 849 & 74.8 & 74.8 & 0 & 3.1 & 3.1 & 0 \\
\hline 859 & 72.1 & 72.1 & 0 & 3.8 & 3.8 & 0 \\
\hline 870 & 74.4 & 120.8 & -46.4 & 4.6 & 5.2 & -0.6 \\
\hline 880 & 78.0 & 120.8 & -42.8 & 5.4 & 6.4 & -1.0 \\
\hline 890 & 81.8 & 120.8 & -39.0 & 6.2 & 7.6 & -1.4 \\
\hline 901 & 78.0 & 120.8 & -42.8 & 7.1 & 8.9 & -1.8 \\
\hline 921 & 76.0 & 120.8 & -44.8 & 8.6 & 11.3 & -2.7 \\
\hline 931 & 83.3 & 120.8 & -37.5 & 9.5 & 12.5 & -3.0 \\
\hline 941 & 75.4 & 120.8 & -45.4 & 10.2 & 13.7 & -3.5 \\
\hline 952 & 78.3 & 120.8 & -42.5 & 11.1 & 15.1 & -4.0 \\
\hline 962 & 79.4 & 120.8 & -41.4 & 11.9 & 16.3 & -4.4 \\
\hline 973 & 74.0 & 120.8 & -46.8 & 12.7 & 17.6 & -4.9 \\
\hline 983 & 85.3 & 120.8 & -35.5 & 13.5 & 18.8 & -5.3 \\
\hline 993 & 82.8 & 120.8 & -38.0 & 14.4 & 20.0 & -5.6 \\
\hline 1004 & 90.8 & 120.8 & -30.0 & 15.4 & 21.3 & -5.9 \\
\hline 1025 & 80.0 & 120.8 & -40.8 & 17.0 & 23.9 & -6.9 \\
\hline 1035 & 79.8 & 120.8 & -41.2 & 17.8 & 25.1 & -7.3 \\
\hline 1045 & 79.2 & 120.8 & -41.6 & 18.6 & 26.3 & -7.7 \\
\hline 1056 & 81.0 & 120.8 & -39.8 & 19.5 & 27.6 & -8.1 \\
\hline 1066 & 84.0 & 120.8 & -36.8 & 20.4 & 28.8 & -8.4 \\
\hline 1077 & 98.4 & 120.8 & -22.4 & 21.4 & 30.2 & -8.8 \\
\hline 1087 & 105.9 & 120.8 & -14.9 & 22.5 & 31.4 & -8.9 \\
\hline 1097 & 110.5 & 120.8 & -10.3 & 23.6 & 32.6 & -9.0 \\
\hline 1108 & 104.2 & 120.8 & -16.6 & 24.7 & 33.9 & -9.2 \\
\hline 1129 & 137.8 & 120.8 & 17.0 & 27.6 & 36.4 & -8.8 \\
\hline 1139 & 158.9 & 120.8 & 38.1 & 29.2 & 37.6 & -8.4 \\
\hline 1149 & 155.1 & 120.8 & 34.3 & 30.8 & 38.9 & -8.1 \\
\hline 1160 & 218.8 & 120.8 & 98.0 & 33.2 & 40.2 & -7.0 \\
\hline 1170 & 205.5 & 120.8 & 84.7 & 35.2 & 41.4 & -6.2 \\
\hline 1181 & 222.2 & 120.8 & 101.4 & 37.7 & 42.7 & -5.0 \\
\hline 1191 & 273.4 & 120.8 & 152.6 & 40.4 & 43.9 & -3.5 \\
\hline 1201 & 346.2 & 120.8 & 225.4 & 43.9 & 45.1 & -1.2 \\
\hline 1212 & 189.5 & 120.8 & 68.7 & 46.0 & 46.5 & -0.5 \\
\hline 1233 & 145.4 & 120.8 & 24.6 & 49.0 & 49.0 & 0.0 \\
\hline 1243 & 126.6 & 120.8 & 5.8 & 50.3 & 50.2 & 0.1 \\
\hline 1253 & 111.2 & 120.8 & -9.6 & 51.4 & 51.4 & 0.0 \\
\hline 1264 & 101.5 & 101.5 & 0 & 52.5 & 52.5 & 0.0 \\
\hline 1274 & 98.9 & 98.9 & 0 & 53.5 & 53.5 & 0.0 \\
\hline 1285 & 101.0 & 101.0 & 0 & 54.6 & 54.6 & 0.0 \\
\hline 1295 & 100.6 & 100.6 & 0 & 55.6 & 55.6 & 0.0 \\
\hline 1305 & 110.6 & 110.6 & 0 & 56.7 & 56.7 & 0.0 \\
\hline 1316 & 101.9 & 101.9 & 0 & 57.8 & 57.8 & 0.0 \\
\hline 1336 & 103.6 & 103.6 & 0 & 59.9 & 59.9 & 0.0 \\
\hline 1347 & 100.4 & 100.4 & 0 & 61.0 & 61.0 & 0.0 \\
\hline 1357 & 98.2 & 98.2 & 0 & 62.0 & 62.0 & 0.0 \\
\hline 1368 & 104.6 & 104.6 & 0 & 63.2 & 63.2 & 0.0 \\
\hline 1378 & 102.1 & 102.1 & 0 & 64.2 & 64.2 & 0.0 \\
\hline
\end{tabular}

the ugandite sample. The fully crystalline olivine basalt has a modal composition of approximately $26 \%$ olivine, $32 \%$ plagioclase, $19 \%$ clinopyroxene, $12 \%$ titanomagnetite, and $9 \%$ alkali feldspar at $900^{\circ} \mathrm{C}$. Calorimetric measurements were collected between 820 and $1422^{\circ} \mathrm{C}$; heat capacities are reported in Table 3 and Fig. 2. In contrast to the ugandite $C_{p}$ profile, the most striking feature in Fig. 2 is the lack of a well-defined peak at the liquidus temperature. From quenched melting experiments undergoing the same thermal history as in the calorimetric run, it is clear that $\sim 85 \%$ of the rock has melted by $1260^{\circ} \mathrm{C}$, yet olivine and spinel do not disappear until $1343^{\circ} \mathrm{C}$. In contrast to the ugandite, the last $15 \%$ of melting occurs over $80^{\circ} \mathrm{C}$. There is only a subtle reflection of this feature in the calorimetric curve. In contrast, the solidus is fairly well marked by the bump in the calorimetric curve that begins at $\sim 935^{\circ} \mathrm{C}$ and marks the initial melting of alkali feldspar. The more significant rise in the $\mathrm{C}_{\mathrm{p}}$ curve, which begins at $\sim 1050^{\circ} \mathrm{C}$ and peaks at $\sim 1170^{\circ} \mathrm{C}$, corresponds to the melting of both plagioclase and clinopyroxene, which are completely gone by $1200^{\circ} \mathrm{C}$. Quench melting experi- 
Table 3 Olivine basalt heat capacity and enthalpy data a Based on the assumption of a uniform distribution of latent heat

\begin{tabular}{|c|c|c|c|c|c|c|}
\hline $\begin{array}{l}\text { Temp } \\
\mathrm{K}\end{array}$ & $\begin{array}{l}\mathrm{Cp} \\
\mathrm{J} / \mathrm{gfw}-\mathrm{K} \\
\text { (meas) }\end{array}$ & $\begin{array}{l}\mathrm{Cp} \\
\mathrm{J} / \mathrm{gfw}-\mathrm{K} \\
\text { (calc) }^{\mathrm{a}}\end{array}$ & $\begin{array}{l}\Delta \\
\mathrm{J} / \mathrm{gfw}-\mathrm{K}\end{array}$ & $\begin{array}{l}\mathrm{H}_{\mathrm{T}}-\mathrm{H}_{\mathrm{Ts}} \\
\mathrm{kJ} / \mathrm{gfw} \\
\text { (meas) }\end{array}$ & $\begin{array}{l}\mathrm{H}_{\mathrm{T}}-\mathrm{H}_{\mathrm{Ts}} \\
\mathrm{kJ} / \mathrm{gfw} \\
\text { (calc) }^{\mathrm{a}}\end{array}$ & $\begin{array}{l}\Delta \\
\mathrm{kJ} / \mathrm{gfW}\end{array}$ \\
\hline 810 & - & - & - & 0 & 0 & 0 \\
\hline 820 & 81.4 & 81.4 & 0 & 0.8 & 0.8 & 0 \\
\hline 830 & 78.7 & 78.7 & 0 & 1.6 & 1.6 & 0 \\
\hline 840 & 82.3 & 82.3 & 0 & 2.4 & 2.4 & 0 \\
\hline 851 & 84.1 & 84.1 & 0 & 3.3 & 3.3 & 0 \\
\hline 861 & 78.5 & 78.5 & 0 & 4.1 & 4.1 & 0 \\
\hline 872 & 81.8 & 81.8 & 0 & 5.0 & 5.0 & 0 \\
\hline 882 & 82.1 & 82.1 & 0 & 5.9 & 5.9 & 0 \\
\hline 892 & 86.7 & 86.7 & 0 & 6.7 & 6.7 & 0 \\
\hline 903 & 85.4 & 85.4 & 0 & 7.7 & 7.7 & 0 \\
\hline 924 & 85.6 & 85.6 & 0 & 9.5 & 9.5 & 0 \\
\hline 934 & 94.3 & 94.3 & 0 & 10.4 & 10.4 & 0 \\
\hline 944 & 95.8 & 95.8 & 0 & 11.4 & 11.4 & 0 \\
\hline 955 & 93.1 & 93.1 & 0 & 12.4 & 12.4 & 0 \\
\hline 965 & 98.9 & 112.0 & -13.1 & 13.4 & 13.5 & -0.1 \\
\hline 976 & 91.5 & 112.0 & -20.5 & 14.4 & 14.7 & -0.4 \\
\hline 986 & 84.9 & 112.0 & -27.1 & 15.2 & 15.9 & -0.6 \\
\hline 996 & 96.5 & 112.0 & -15.5 & 16.2 & 17.0 & -0.8 \\
\hline 1007 & 95.7 & 112.0 & -16.3 & 17.2 & 18.2 & -1.0 \\
\hline 1028 & 102.9 & 112.0 & -9.1 & 19.4 & 20.6 & -1.2 \\
\hline 1038 & 99.7 & 112.0 & -12.3 & 20.4 & 21.7 & -1.3 \\
\hline 1048 & 92.5 & 112.0 & -19.5 & 21.3 & 22.8 & -1.5 \\
\hline 1059 & 100.6 & 112.0 & -11.4 & 22.4 & 24.0 & -1.6 \\
\hline 1069 & 96.1 & 112.0 & -15.9 & 23.4 & 25.2 & -1.8 \\
\hline 1080 & 112.0 & 112.0 & 0 & 24.6 & 26.4 & -1.8 \\
\hline 1090 & 110.8 & 112.0 & -1.2 & 25.7 & 27.5 & -1.8 \\
\hline 1100 & 117.7 & 112.0 & 5.7 & 26.9 & 28.6 & -1.7 \\
\hline 1111 & 104.8 & 112.0 & -7.2 & 28.1 & 29.9 & -1.8 \\
\hline 1133 & 134.4 & 112.0 & 22.4 & 31.0 & 32.3 & -1.3 \\
\hline 1143 & 140.5 & 112.0 & 28.5 & 32.4 & 33.4 & -1.0 \\
\hline 1153 & 155.9 & 112.0 & 43.9 & 34.0 & 34.6 & -0.6 \\
\hline 1164 & 153.6 & 112.0 & 41.6 & 35.7 & 35.8 & -0.1 \\
\hline 1174 & 159.1 & 112.0 & 47.1 & 37.3 & 36.9 & +0.4 \\
\hline 1185 & 135.3 & 112.0 & 23.3 & 38.8 & 38.1 & +0.6 \\
\hline 1195 & 106.0 & 112.0 & -6.0 & 39.8 & 39.3 & +0.6 \\
\hline 1205 & 114.1 & 112.0 & 2.1 & 41.0 & 40.4 & +0.6 \\
\hline 1216 & 118.1 & 112.0 & 6.1 & 42.3 & 41.6 & +0.6 \\
\hline 1236 & 112.8 & 112.0 & 0.8 & 44.5 & 43.9 & +0.7 \\
\hline 1247 & 111.8 & 112.0 & -0.2 & 45.7 & 45.1 & +0.7 \\
\hline 1257 & 118.9 & 112.0 & 6.9 & 46.9 & 46.2 & +0.7 \\
\hline 1268 & 96.8 & 112.0 & -15.2 & 48.0 & 47.4 & +0.6 \\
\hline 1278 & 100.8 & 112.0 & -11.2 & 49.0 & 48.6 & +0.4 \\
\hline 1288 & 100.5 & 112.0 & -11.5 & 50.0 & 49.7 & +0.3 \\
\hline 1299 & 112.3 & 112.0 & 0.3 & 51.2 & 50.9 & +0.3 \\
\hline 1309 & 101.7 & 112.0 & -10.3 & 52.3 & 52.0 & +0.2 \\
\hline 1319 & 103.6 & 112.0 & -8.4 & 53.3 & 53.2 & +0.1 \\
\hline 1339 & 104.2 & 112.0 & -7.8 & 55.4 & 55.4 & 0 \\
\hline 1350 & 98.4 & 98.4 & 0 & 56.5 & 56.5 & 0 \\
\hline 1360 & 102.3 & 102.3 & 0 & 57.5 & 57.5 & 0 \\
\hline 1371 & 105.1 & 105.1 & 0 & 58.7 & 58.7 & 0 \\
\hline 1381 & 99.9 & 99.9 & 0 & 59.7 & 59.7 & 0 \\
\hline 1391 & 102.6 & 102.6 & 0 & 60.7 & 60.7 & 0 \\
\hline 1402 & 100.9 & 100.9 & 0 & 61.8 & 61.8 & 0 \\
\hline 1412 & 101.6 & 101.6 & 0 & 62.8 & 62.8 & 0 \\
\hline 1422 & 100.2 & 100.2 & 0 & 63.8 & 63.8 & 0 \\
\hline
\end{tabular}

ments further indicate that by $1050^{\circ} \mathrm{C}, \sim 30 \%$ of the rock is melted and over the next $160^{\circ} \mathrm{C}\left(1050-1210^{\circ} \mathrm{C}\right)$ an additional $50 \%$ of the rock melts. This latter pulse of melting is easily resolved by the calorimetric measurements. Again, the melt fraction across the liquidussolidus interval is far from linear.

The distribution of enthalpy across the liquidussolidus interval for the olivine basalt was calculated by integration of the heat capacity curve in Fig. 2 using the relationship in Eq. 1. Again, area integration was performed by cubic interpolation of the data points with the stipulation that at $1170^{\circ} \mathrm{C}$, the $\mathrm{C}_{\mathrm{p}}$ reaches a maximum. Values of $\mathrm{H}_{\mathrm{T}}-\mathrm{H}_{\mathrm{Ti}}$ for the olivine basalt are listed in Table 3. The total enthalpy of fusion is $43 \mathrm{~kJ} / \mathrm{gfw}$ for the initially crystalline rock. 


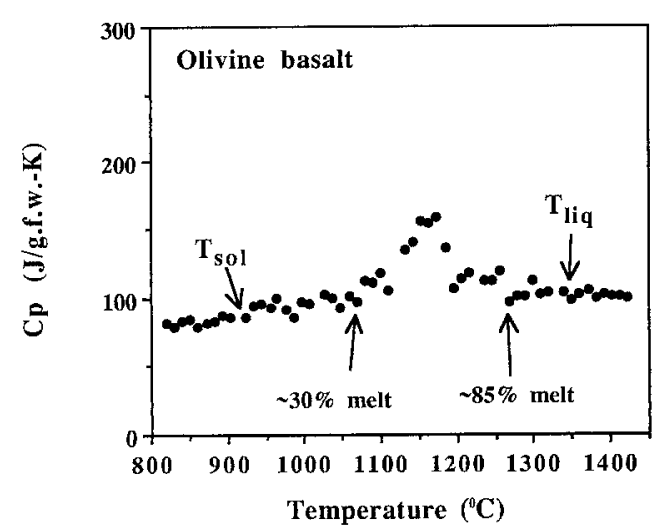

Fig. 2 Plot of measured heat capacity vs temperature during melting of the basalt. $\mathrm{T}_{\text {sol }}$ and $\mathrm{T}_{\text {liq }}$ refer to the solidus and liquidus temperaures respectively
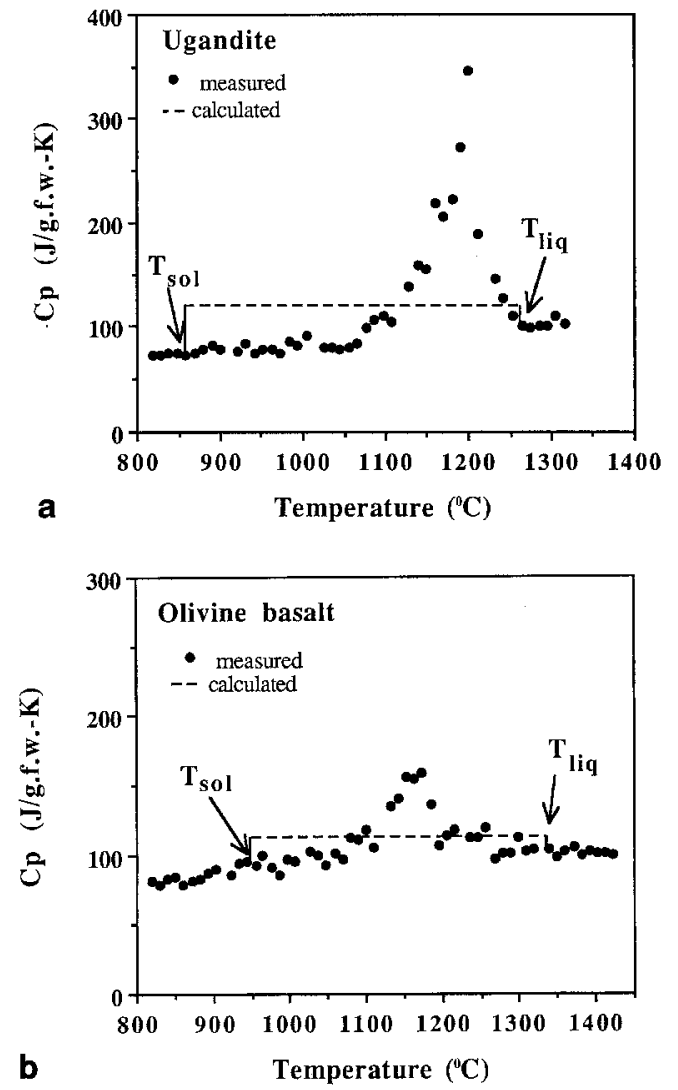

Fig. 3a,b Comparison of the measured heat capacity curves during melting of $\mathbf{a}$ the ugandite and $\mathbf{b}$ the basalt with those calculated (dashed curves) assuming a uniform distribution of latent heat. By defintion, integrations of the measured and calculated heat capacity curves lead to the same enthalpy of fusion for each sample

How good is the assumption of a uniform distribution of latent heat?

We can now compare our in-situ measurements of latent heat during melting of the ugandite and olivine basalt samples with the common assumption that latent heat is

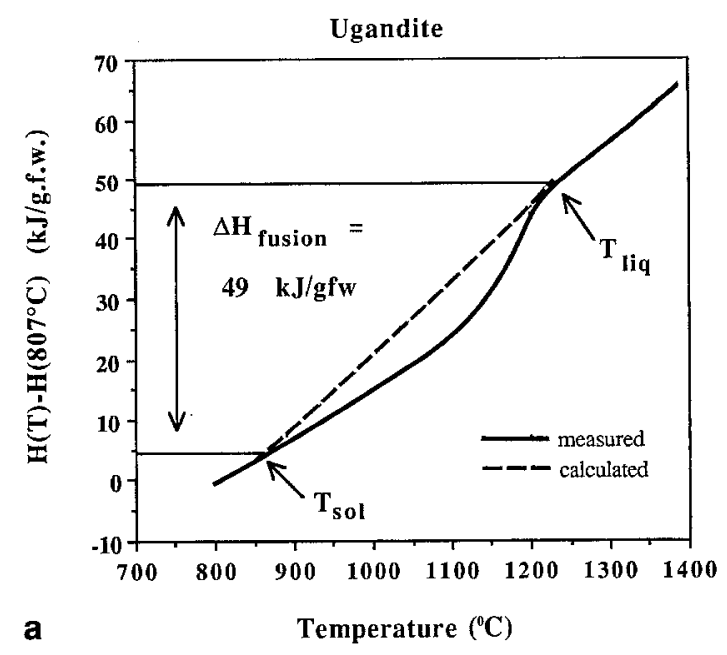

Olivine basalt

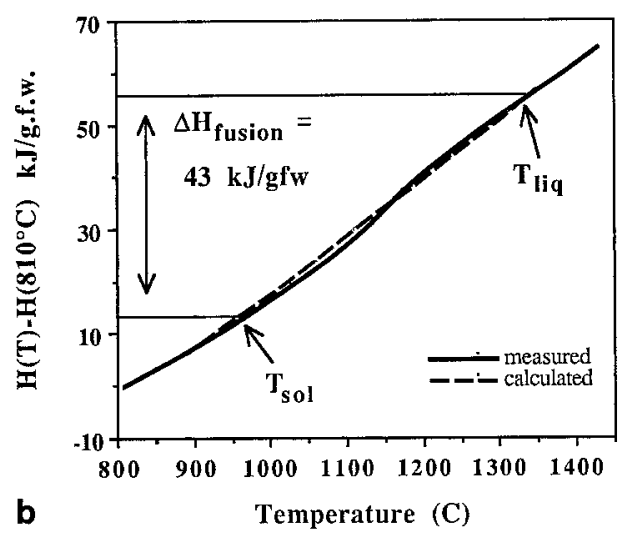

Fig. 4a, b Comparison of a calculated "uniform" distribution of enthalpy (dashed curve) with that obtained by in-situ measurements (solid curve) for a the ugandite and $\mathbf{b}$ the olivine basalt

distributed uniformly across the liquidus-solidus interval. We calculated the area under the measured $C_{p}$ curves in Figs. 1 and 2 and then redistributed the same area uniformly between the solidus and liquidus of each sample, as seen in Fig. $3 a$ and $3 b$. The calculated $C_{p}$ value across the liquidus-solidus interval for each sample is listed in Tables 2 and 3 for comparison to the measured values. Integration of the "uniform" $\mathrm{C}_{\mathrm{p}}$ curves was performed using the relation in Eq. 1; the "uniform" distribution of enthalpy is compared with that obtained from our in-situ measurements in Tables 2 and 3 and Fig. 4a,b. By definition, integration of the "uniform" $\mathrm{C}_{\mathrm{p}}$ curve leads to the same total enthalpy of fusion between the solidus and liquidus for each sample. What is different, however, is the rate at which heat is absorbed (or released) during melting (or crystallization) as a function of temperature. We can now use the measured and calculated distributions of enthalpy for each sample to infer cooling histories.

For example, examination of the in-situ enthalpy measurements on the ugandite sample (Fig. 4a) indicates that latent heat will be released at a faster rateper 
increment drop in temperature relative to a model in which latent heat is distributed uniformly across the crystallization interval. This is caused by cotectic precipitation of leucite and clinopyroxene, leading to a large, disproportionate release of latent heat early in the crystallization sequence. This requires that the rate of heat loss during conductive cooling of this ugandite magma will initially be more rapid than the average rate. The net result will be to produce lower magmatic temperatures after a given cooling interval, relative to models assuming a uniform release of latent heat.

Ghiorso (1991) observed the same phenomenon when modelling the conductive cooling path of an olivine tholeiite from Thingmuli, Iceland. In that study, Ghiorso's thermodynamic model (Ghiorso et al. 1983) was used to show that olivine, plagioclase, and clinopyroxene all crystallize within $30^{\circ} \mathrm{C}$ of the liquidus temperature. Just as in the case of the ugandite magma, there is a disproportionately large release of latent heat accompanying this cotectic precipitation that occurs early in the crystallization interval. Ghiorso (1991) further showed that the assumption of a uniform distribution of heat leads to an overestimation of the magmatic temperature (during conductive cooling of a $1000 \mathrm{~km}^{3}$ olivine tholeiite magma body) by as much $60^{\circ} \mathrm{C}$ after 500,000 years of cooling, and $\sim 100^{\circ} \mathrm{C}$ after 700,000 years of cooling. In other words, the crustal residence time of a cooling olivine tholeiitic magma body will be overestimated. Similar conclusions can be drawn regarding the cooling history of the ugandite magma body or any magma which crystallizes a large proportion of phases (i.e., reaches a cotectic) early in its crystallization sequence.

The distribution of latent heat across the liquidussolidus interval of the olivine basalt is in direct contrast to this behavior. Unlike the ugandite, the olivine basalt undergoes a protracted crystallization sequence in which olivine is the dominant precipitating phase for over $200^{\circ} \mathrm{C}$ before the system reaches a cotectic, first with clinopyroxene and then with plagioclase. Although there is a large release of latent heat at this point, the important aspect is that it occurs approximately in the middle of the liquidus-solidus interval. In Fig. 4b, the distribution of enthalpy derived assuming a uniform release of latent heat is very similar to that derived from our in-situ measurements. In other words, the approximation of a uniform distribution of latent heat is quite good for the olivine basalt sample. This behavior is similar to that calculated by Ghiorso (1991) for a boninite magma. In that study, Ghiorso's thermodynamic model was used to demonstrate that a boninite magma also undergoes a long crystallization sequence in which orthopyroxene is the only precipitating phase for over $200^{\circ} \mathrm{C}$ until it finally reaches a cotectic with plagioclase. Again, the large pulse of released latent heat occurs approximately midway through a long, protracted liquidus-solidus interval. The conductive cooling model of Ghiorso (1991) demonstrates that the approximation of a uniform distribution of latent heat is a good one for the boninite, primarily because the large heat release at the cotectic occurs in the middle of the crystallization sequence.

A corollary to these observations is that a magma undergoing signficant crystallization at temperatures very close to the solidus (e.g., crustal melts under watersaturated conditions; see Wyllie 1977; Wickham 1987) will not be well approximated as having a uniform distribution of latent heat. For such magmas, there will be a disproportionate release of latent heat late in the crystallization sequence. In this case, the rate of heat loss during conductive cooling will initially (near the liquidus) be slower than the average rate. The net result will be to predict higher magmatic temperatures after a given cooling interval relative to models assuming a uniform release of latent heat. In other words, the crustal residence time for such a cooling magma body will be underestimated.

\section{Enthalpy profiles during melting and crystallization as a function of cooling and heating rates}

An additional series of scanning calorimetric experiments were performed to evaluate the role of kinetics on the distribution of enthalpy during melting and crystallization. During these runs, the thermopile voltage was monitored as each sample was cooled and heated at a given rate $(1,2$ and $3 \% \mathrm{~min})$. The calorimetric signal is directly proportional to the "instantaneous" release or absorption of latent heat during crystallization and melting, respectively. These experiments demonstrate that a variation in cooling and heating rate can give rise to dramatically different enthalpy profiles (Fig. 5).

Another goal of the scanning experiments was to determine the minimum heat content per unit time that can be resolved by the calorimeter during these rapid scans. A series of BSE photographs (Figs. 6, 7) were taken of both the olivine basalt and ugandite samples quenched from simulated heating and cooling experiments at two different rates: $3^{\circ}$ and $1^{\circ} / \mathrm{min}$. Quench temperatures closely correspond to the beginning, peak, and final temperatures over which a heat effect could be resolved from the respective calorimetric curves in Fig. 5. Tables 4 and 5 list the modes for each sample, allowing correlation of mineral abundance to "key" regions along the calorimetric curves. Quantification of the modes allows constraints to be placed on the minimum extent of crystallization (or melting) of various mineral phases that can be detected. In other words, it is possible to determine how much of each phase per unit time must be crystallizing (or melting) in order to be resolved by the calorimetric signal.

\section{Olivine basalt: heating and cooling scans}

The results of heating and cooling scans at variable rates $\left(1,2\right.$, and $\left.3^{\circ} / \mathrm{min}\right)$ for the olivine basalt are present- 
Fig. 5 a The results of a series of crystallization and melting experiments on the olivine basalt in the calorimeter at constant cooling and heating rates of $3^{\circ}, 2^{\circ}$, and $1^{\circ} / \mathrm{min}$. b The results of a series of crystallization and melting experiments on the ugandite in the calorimeter at constant cooling and heating rates of $3^{\circ}, 2^{\circ}$, and $1^{\circ} / \mathrm{min}$
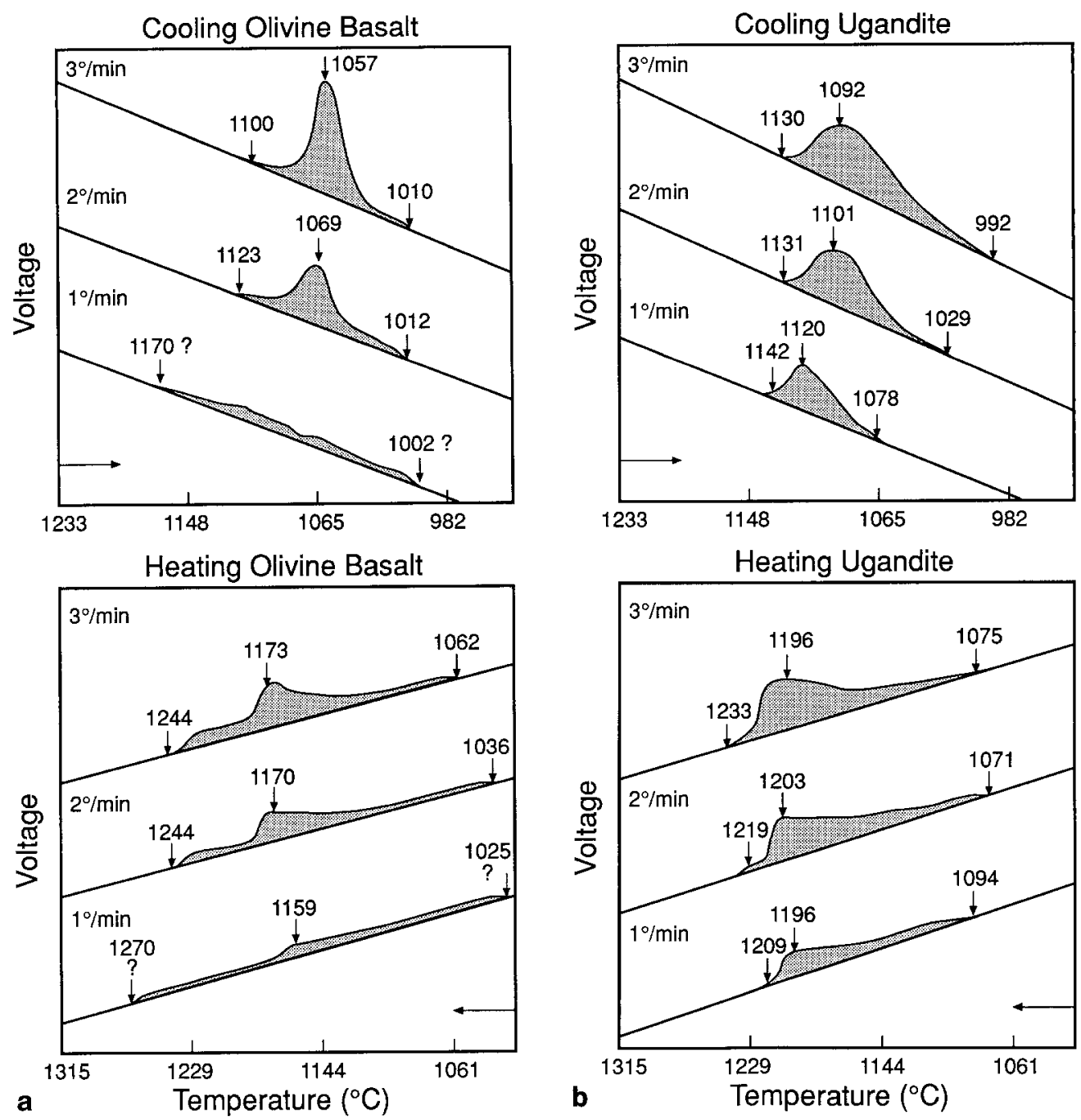

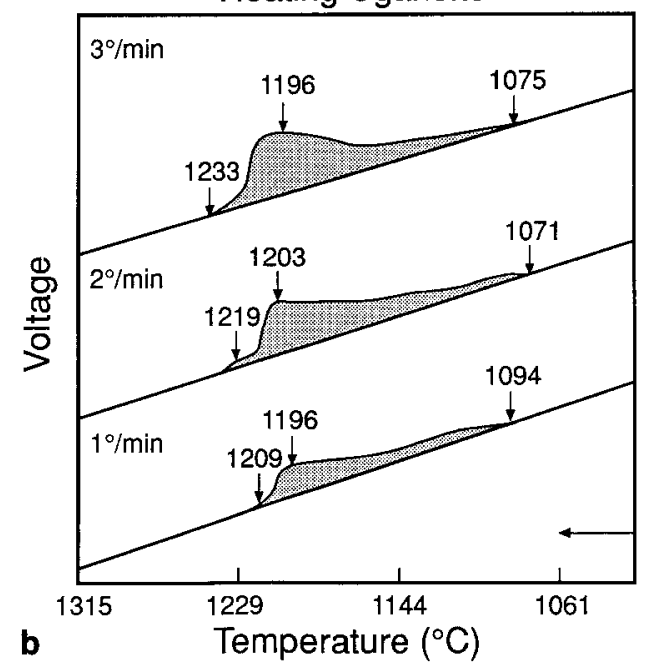

ed in Fig. 5a. Prior to each run, the samples were taken to $1300^{\circ} \mathrm{C}$, held for six hours, and then cooled slowly $\left(5^{\circ} / \mathrm{h}\right)$ to $800^{\circ} \mathrm{C}$. For the heating runs, the experiments then began at $800^{\circ} \mathrm{C}$.

In Fig. 5a, it can be seen that the temperature interval over which a heat effect can be resolved for the olivine basalt is a function of both (1) whether the sample is being heated or cooled and (2) the scanning rate. For relatively rapid $\left(3^{\circ} / \mathrm{min}\right)$ heating and cooling scans, the heat effect is resolved over intervals of 186 and $90^{\circ} \mathrm{C}$, respectively. The highest temperature for which a heat effect can be resolved is $1248^{\circ} \mathrm{C}$ for the heating scan and $1100^{\circ} \mathrm{C}$ for the cooling scan. The modal data (Table 4) show that the upper temperature limits correspond to melt fractions of 0.96 at $1248^{\circ} \mathrm{C}$ during heating and 0.89 at $1100^{\circ} \mathrm{C}$ during cooling. The difference between the two melt fractions is small (.07), given the estimated error in the modes $( \pm .05)$. Therefore, the large difference in the upper limit temperatures $\left(1248\right.$ and $\left.1100^{\circ} \mathrm{C}\right)$ primarily reflects the kinetic suppression of nucleation and crystallization during rapid cooling compared to kinetic hindrances to melting during heating. There is very litttle difference in the lower temperature limits (for which a heat effect can be resolved) between the rapid heating and cooling scans $\left(1062\right.$ and $1025^{\circ} \mathrm{C}$, respectively); both lower temperatures correspond to a melt fraction of 0.72 (Table 4).

For the slower heating and cooling scans $\left(1^{\circ} / \mathrm{min}\right)$, the latent heat effect is resolved over larger temperature intervals relative to the faster scans $\left(3^{\circ} / \mathrm{min}\right)$. During heating, the temperature interval is $235^{\circ} \mathrm{C}$ at $1^{\circ} / \mathrm{min}$ (vs $186^{\circ} \mathrm{C}$ at $3^{\circ} / \mathrm{min}$ ), whereas during cooling, the interval is 168 (vs 90) ${ }^{\circ} \mathrm{C}$. The highest temperature for which a heat effect can be resolved is $\sim 1270^{\circ} \mathrm{C}$ for the heating scan and $\sim 1170^{\circ} \mathrm{C}$ for the cooling scan; both upper limit temperatures correspond to a melt fraction of $\sim 0.92$. Again, the difference in the upper limit temperatures $\left(1270\right.$ vs $\left.1170^{\circ} \mathrm{C}\right)$ can be attributed to kinetic delays in nucleation during cooling. As observed for the rapid scans, there is not much difference in the lower temperature limits (1025 and $1002^{\circ} \mathrm{C}$, respectively) between the heating and cooling scans at $1 \% \mathrm{~min}$; both temperatures correspond to melt fractions of 0.68 (Table 4).

The most striking feature of the basalt heating and cooling scans at both $3^{\circ}$ and $1 \% \mathrm{~min}$ is that the latent heat profiles only reflect $\sim 20-30 \%$ melting and crystal- 

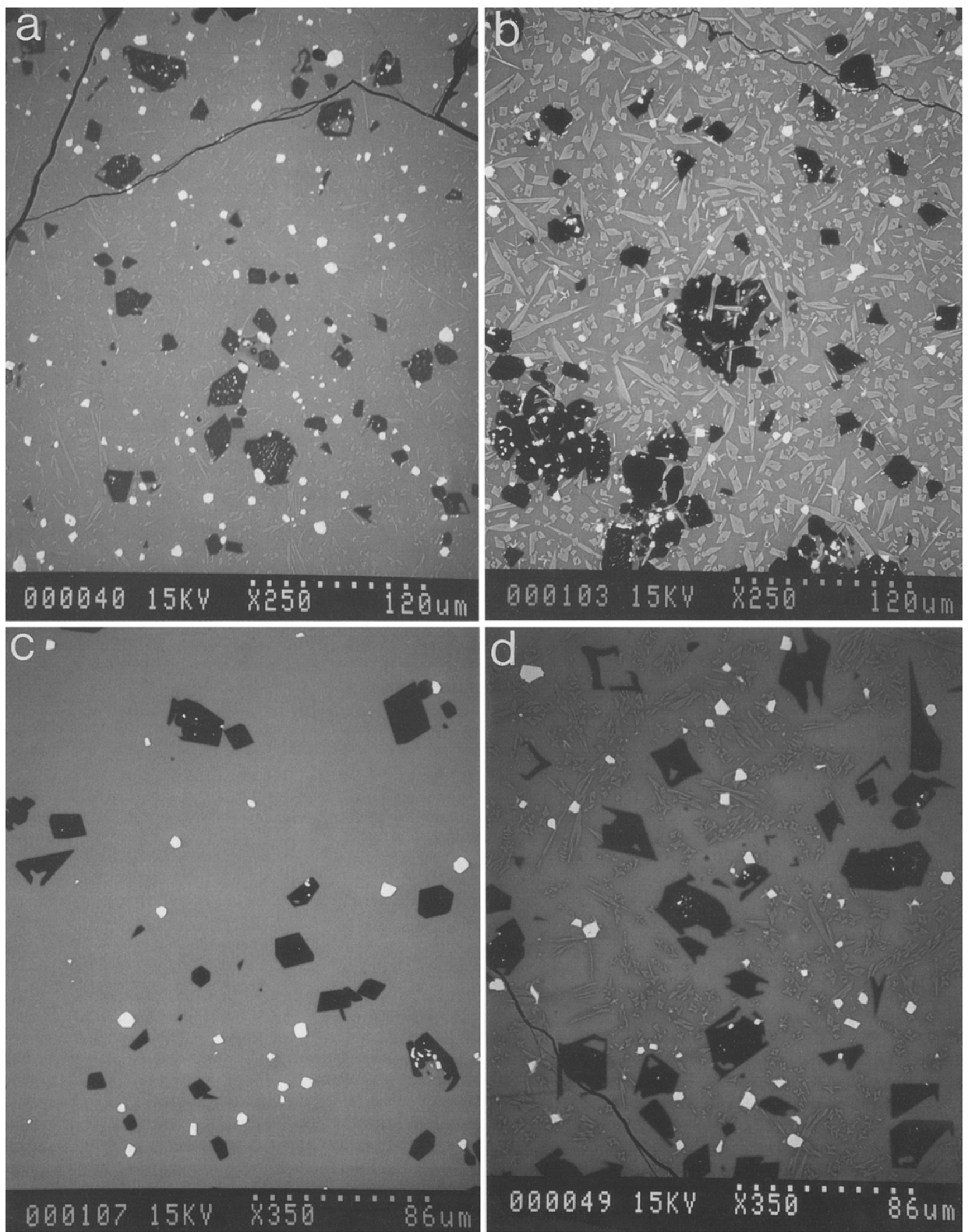

Fig. 6a-d Representative BSE images of the olivine basalt sample, a quenched at $1144^{\circ} \mathrm{C}$ from a heating $\left(3^{\circ} / \mathrm{min}\right)$ run, $\mathbf{b}$ quenched at $1025^{\circ} \mathrm{C}$ from a heating $\left(1^{\circ} / \mathrm{min}\right)$ run, $\mathbf{c}$ quenched at $1170^{\circ} \mathrm{C}$ from

a cooling $\left(1^{\circ} / \mathrm{min}\right)$ run $\mathbf{d}$ quenched at $1057^{\circ} \mathrm{C}$ from a cooling $\left(3^{\circ}\right)$ min) run. In order from darkest to lightest, the phases are olivine, glass, clinopyroxene, and spinel 

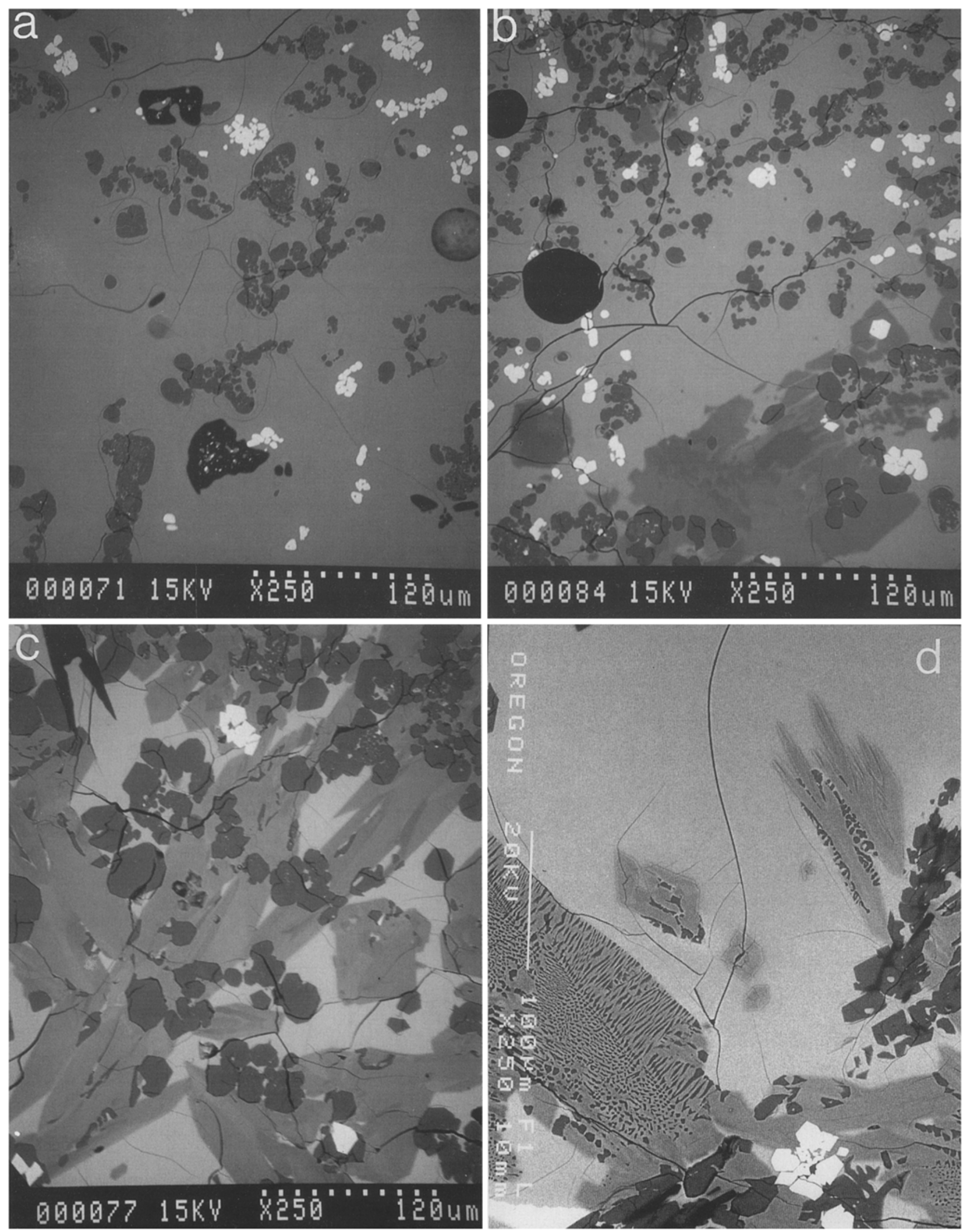

Fig. 7a-d Representative BSE images of the ugandite sample, a quenched at $1232^{\circ} \mathrm{C}$ from a heating $\left(3^{\circ} / \mathrm{min}\right)$ run, $\mathbf{b}$ quenched at $1209^{\circ} \mathrm{C}$ from a heating $\left(1^{\circ} / \mathrm{min}\right)$ run, c quenched at $1095^{\circ} \mathrm{C}$ from a

cooling $\left(3^{\circ} / \mathrm{min}\right)$ run, $\mathbf{d}$ quenched at $1142^{\circ} \mathrm{C}$ from a cooling $\left(1^{\circ}\right)$ min) run. In order from darkest to lightest, the phases are olivine, leucite, clinopyroxene, glass, and spinel 
Table 4 Modal \% of mineral phases during basalt scans

\begin{tabular}{lccc}
\hline $3^{\circ} /$ min: heating & & & \\
Temperature & $1248^{\circ} \mathrm{C}$ & $1200^{\circ} \mathrm{C}$ & $1062^{\circ} \mathrm{C} ?$ \\
Glass & 96 & 91 & 72 \\
Spinel & $<1$ & $<1$ & 1 \\
Clinopyroxene & - & - & 14 \\
Olivine & 4 & 8 & 13 \\
$3^{\circ} /$ minute: cooling & & & \\
Temperature & $1100^{\circ} \mathrm{C}$ & $1057^{\circ} \mathrm{C}$ & $1010^{\circ} \mathrm{C}$ \\
Glass & 89 & 80 & 72 \\
Spinel & 1 & 1 & 2 \\
Clinopyroxene & - & 14 & 19 \\
Olivine & 10 & 5 & 7 \\
$1^{\circ} /$ minute: heating & & & \\
Temperature & $1260^{\circ} \mathrm{C}$ & $1165^{\circ} \mathrm{C}$ & $1025^{\circ} \mathrm{C}$ \\
Glass & 93 & 84 & 68 \\
Spinel & $<1$ & 2 & 2 \\
Clinopyroxene & - & 6 & 23 \\
Olivine & 5 & 6 & 8 \\
$1^{\circ} /$ minute: cooling & & & \\
Temperature & $1170^{\circ} \mathrm{C}$ & $1078^{\circ} \mathrm{C}$ & $1010^{\circ} \mathrm{C}$ \\
Glass & 91 & 77 & 68 \\
Spinel & $<1$ & 2 & 2 \\
Clinopyroxene & - & 10 & 30 \\
Olivine & 8 & 8 & 5 \\
\hline
\end{tabular}

lization. The modes in Table 4 indicate that plagioclase never crystallized during the cooling runs and was never present at the beginning of a heating run. This reflects the sluggish nucleation of feldspar in the basalt liquid. Prior to the heating runs, the olivine basalt was not held at $800^{\circ} \mathrm{C}$ long enough (only $6 \mathrm{~h}$ ) to crystallize feldspar. In contrast, prior to the step-scanning run of the olivine basalt (results shown in Fig. 2), the sample was held for $48 \mathrm{~h}$. The presence of crystalline feldspar at the beginning of the step-scanning experiment, in addition to the improved detection limits when running in step-scanning vs scanning mode (see Lange et al. 1991 for detailed discussion), led to the vastly different calorimetric profiles observed during heating of the olivine basalt at $1 \%$ min between Fig. 2 and Fig. 5.

It should also be noted that the sharp peak observed for the olivine basalt sample during the rapid cooling scan $(3 \% \mathrm{~min})$ corresponds to the onset of clinopyroxene crystallization during cooling ( $\sim 14 \%$ at the peak temperature). In marked contrast, during the slower cooling scan, the effect of clinopyroxene $\left(\sim 10 \%\right.$ at $\left.1078^{\circ} \mathrm{C}\right)$ is barely detected in the calorimetric signal. Again, the differences between the two profiles (rapid vs slow cooling), can be attributed to how much heat per unit time can be resolved with the calorimeter.

\section{Ugandite: heating and cooling scans}

The results of heating and cooling scans at variable rates $\left(1,2\right.$, and $\left.3^{\circ} / \mathrm{min}\right)$ for the ugandite are presented in Fig. 5b. Prior to each run, the samples were taken to
Table 5 Modal \% of mineral phases during ugandite scans. (In this sample, the distribution of phases was heterogeneous with scattered clots of crystals. Errors are also introduced from the fact that the modes are determined from a two-dimensional cross section through a three-dimensional sample volume)

$3 \%$ minute: heating

Temperature

$1232^{\circ} \mathrm{C}$
86
2
-
12
$?$

$1196^{\circ} \mathrm{C}$
65
4
17
22
3

$1075^{\circ} \mathrm{C}$
24
3
43
31
$?$

$3^{\circ} /$ minute: cooling

Temperature

$1130^{\circ} \mathrm{C}$

$1092^{\circ} \mathrm{C}$

$992^{\circ} \mathrm{C}$

Glass

Spinel

Clinopyroxene

Leucite

Olivine

$1^{\circ} /$ minute: heating

Temperature

Glass

Spinel

Clinopyroxene

Leucite

Olivine

$1 \%$ minute: cooling

Temperature

Glass

Spinel

Cinopyroxene"

Leucite

Olivine

87
2
5
6
$?$

$1209^{\circ} \mathrm{C}$
56
2
12
30
$?$

$1192^{\circ} \mathrm{C}^{*}$

44-53

2-3

20-25

19-25

?

$1142^{\circ} \mathrm{C}$
68
4
16
12
$?$

$1120^{\circ} \mathrm{C}$
31
5
31
32
$?$

$1078^{\circ} \mathrm{C}$
28
3
43
26
$?$

$1300^{\circ} \mathrm{C}$, held for $6 \mathrm{~h}$, and then cooled slowly $\left(5^{\circ} / \mathrm{h}\right)$ to $800^{\circ} \mathrm{C}$. For the heating runs, the experiments then began at $800^{\circ} \mathrm{C}$.

One of the striking features of the ugandite scans is that the temperature interval over which a heat effect can be resolved appears to decrease as both the heating and cooling rates decrease; this is opposite to the trend observed for the basalt. For relatively rapid heating and cooling conditions $\left(3^{\circ} / \mathrm{min}\right)$, the heat effect is resolved over 158 and $138^{\circ} \mathrm{C}$ intervals respectively, whereas for slower heating and cooling conditions $\left(1^{\circ} / \mathrm{min}\right)$, the heat effect is resolved over shorter intervals of 115 and $64^{\circ} \mathrm{C}$, respectively.

From Table 5, it is clear that in all four cases (rapid and slow heating; rapid and slow cooling), the lowest temperatures for which the heat effect can be detected all correspond to a relatively constant melt fraction of $\sim 0.2-0.3$. In contrast, the heating and cooling rate determines the extent to which crystallization or melting near the liquidus can be resolved. For example, during rapid $\left(3^{\circ} / \mathrm{min}\right)$ heating and cooling, the highest temperatures for which a heat effect is resolved correspond to a constant melt fraction of $\sim 0.9$, whereas during slow $\left(1^{\circ} / \mathrm{min}\right)$ heating and cooling, the highest temperatures correspond to a melt fraction of $\sim 0.7$. This observation is important in terms of the resolution of the calorime- 
ter. During the slow cooling scan $(1 \% \mathrm{~min})$, a full $30 \%$ of crystallization occurs near the liquidus that is undetected by the calorimetric signal. Again, this demonstrates the sensitivity of the calorimeter to the heat produced per unit time.

The effect of kinetic delays to the nucleation of clinopyroxene is also evident from the ugandite scans at variable cooling rates. For example, the highest temperatures for which a heat effect can be detected are very different between heating and cooling scans performed at the same rate (e.g., 1232 vs $1130^{\circ} \mathrm{C}$ at $3^{\circ} / \mathrm{min}$ and 1209 vs $1142^{\circ} \mathrm{C}$ at $1^{\circ} / \mathrm{min}$ ). As for the olivine basalt, this clearly shows the kinetic suppression of nucleation and crystallization during cooling compared to kinetic hindrances to melting during heating.

An additional important observation that can be drawn from the calorimetric curves relates to the difference in viscosity between the olivine basalt and ugandite liquids. The modal data found in Table 5 indicate that during the rapid scans $\left(3^{\circ} / \mathrm{min}\right)$, the ugandite calorimetric curves reflect $\sim 50-60 \%$ of crystallization and melting; this is twice what is observed for the olivine basalt. This difference is due to the fact that the ugandite melt is significantly more fluid than the olivine basalt melt, allowing leucite to nucleate more readily than plagioclase. Significant crystallization of leucite occurs, therefore, during rapid cooling, and the resulant release of latent heat is observed. Consequently, a significant proportion of leucite $(\sim 30-40 \%)$ is present in the ugandite sample prior to all heating runs; $6 \mathrm{~h}$ at $800^{\circ} \mathrm{C}$ is clearly sufficient time to allow leucite to crystallize fully in the charge. The contribution from the melting of leucite to the latent heat profile is, therefore, always observed during the heating runs.

Detection limits $(\mathrm{kJ} / \mathrm{min})$ of the calorimeter in scanning mode

The minimum amount of heat per unit time that is resolved by the calorimeter can be estimated by calculating how much of any one phase melted or crystallized without detection during various heating or cooling scans. For example, during the $3 \%$ min heating scan of the olivine basalt, the calorimetric signal obtained at temperatures above the peak (signalling the completion of clinopyroxene melting) can be attributed exclusively to the melting of olivine. The data in Table 4 indicate that approximately $4( \pm 2) \mathrm{mol} \%{ }^{2}$ olivine crystallized over a $48^{\circ}$ interval $\left(1248-1240^{\circ} \mathrm{C}\right)$. The curve in Fig. $5 \mathrm{a}$ shows that this was readily detected by the calorimeter. Electron microprobe analyses indicate that the composition of the olivine ranges between $\mathrm{Fo}_{96}$ and $\mathrm{Fo}_{94}$ (the high forsterite content is a consequence of running the experiments in air). The heat of fusion of $\mathrm{Fo}_{95}$ over the

\footnotetext{
${ }^{2}$ Uncertainites in modal abundance are small ( \pm 2 modal \%) when only one mineral phase (not including spinel which is very bright in a back-scattered image) is present.
}

temperature range of 1248 to $1200^{\circ} \mathrm{C}$ can be calculated from the heats of fusion of pure forsterite $(\sim 142 \mathrm{~kJ} / \mathrm{mol}$ at its melting point of $1901^{\circ} \mathrm{C}$; Richet et al. 1993) and pure fayalite $(89.3 \mathrm{~kJ} / \mathrm{mol}$ at the metastable congruent melting point of $1217^{\circ} \mathrm{C}$; Stebbins and Carmichael 1984). Extrapolation of these values to the temperature range of interest was accomplished using the heat capacity for crystalline forsterite and fayalite of Berman (1988) and the heat capacity for liquid $\mathrm{Mg}_{2} \mathrm{SiO}_{4}$ and liquid $\mathrm{Fe}_{2} \mathrm{SiO}_{4}$ calculated from the algorithm of Lange and Navrotsky (1992); these calculations led to a heat of fusion for $\mathrm{FO}_{95}$ of $\sim 74.6 \mathrm{~kJ} / \mathrm{mol}$ between 1244 and $1200^{\circ} \mathrm{C}$. Crystallization of $\sim 4( \pm 2) \mathrm{mol} \%$ olivine over a $48^{\circ} \mathrm{C}$ interval, during cooling at $3^{\circ} / \mathrm{min}$, corresponds to crystallization of $\sim 1.3 \mathrm{~mol} \%$ olivine in $5 \mathrm{~min}$. Therefore, given the heat of fusion of $\mathrm{Fo}_{95}$ of $\sim 74.6 \mathrm{~kJ} / \mathrm{mol}$, the results indicate that $\sim 1.0 \mathrm{~kJ}$ per $5 \mathrm{~min}$ increment can be resolved. The uncertainty in this estimate caused by errors in the estimated modal abundance of olivine is approximately $\pm 0.4 \mathrm{~kJ}$.

We can test this estimate using the crystallization of leucite in the ugandite scans. During the $1 \% \mathrm{~min}$ heating scan, $\sim 16 \mathrm{~mol} \%$ leucite and $\sim 5 \mathrm{~mol} \%$ clinopyroxene still remains in the sample by $1209^{\circ} \mathrm{C}$. Additional quench experiments on the ugandite sample cooled at $1 \%$ min show that $<1 \%$ clinopyroxene and $\sim 10 \mathrm{~mol} \%$ leucite is present in the charge at $1220^{\circ} \mathrm{C}$ and that $<4$ mol\% leucite is present in the charge at $1250^{\circ} \mathrm{C}$. Therefore, between 1250 and $1220^{\circ} \mathrm{C}$, approximately $6 \mathrm{~mol} \%$ of leucite melted and was not detected in the calorimetric signal. We can estimate the heat of fusion for leucite using the value suggested by Ghiorso and Carmichael (1987) of $-3.05 \mathrm{~kJ} / \mathrm{mol}$ at room temperature (a correction of $10 \mathrm{~kJ} / \mathrm{mol}$ from the value given by Kelley 1960 ). Extrapolation of this value up to $1250-1220^{\circ} \mathrm{C}$ was achieved using the heat capacity for crystalline leucite of Robie (1978) and Lange et al. (1986), and the heat capacity for liquid $\mathrm{KAlSi}_{2} \mathrm{O}_{6}$ using the algorithm of Lange and Navrotsky (1992); these calculations led to a heat of fusion for leucite of $\sim 80.5 \mathrm{~kJ} / \mathrm{mol}$ at $1235^{\circ} \mathrm{C}$. Crystallization of $\sim 6( \pm 2) \mathrm{mol} \%$ leucite over a $30^{\circ} \mathrm{C}$ interval, during a heating rate of $1 \% \mathrm{~min}$, corresponds to $\sim 1.0 \mathrm{~mol} \%$ leucite over a $5 \mathrm{~min}$ interval. Using the heat of fusion of $\sim 80.5 \mathrm{~kJ} / \mathrm{mol}$ for leucite indicates that the production of $\sim 0.81 \mathrm{~kJ}$ per $5 \mathrm{~min}$ increment could not be resolved. Given the error in this estimate of approximately $\pm 0.4 \mathrm{~kJ}$, as well as the results presented above for olivine, the detection limit is probably not less than $0.6 \mathrm{~kJ}$ and not more than $1.2 \mathrm{~kJ}$ per 5 min increment. This range is within the detection limit estimated by Lange et al. (1991) of 1-1.2 kJ per 5 min interval, based on cooling scans $(1 \% \mathrm{~min})$ of diopside liquid.

\section{Conclusions}

Continuous scanning experiments provide a "snapshot" picture of the instaneous release (or absorption) of enthalpy, and can thus be applied to studies of crystal- 
lization and melting as a function of cooling and heating rate. Kinetic information can only be obtained, howev$\mathrm{er}$, when the detection limit of the calorimeter (between $0.6-1.2 \mathrm{~kJ}$ per $5 \mathrm{~min}$ increment) is taken into account. The important parameter is the release or absorption of heat per unit time, thus rapid scans tend to give sharper profiles relative to slow ones.

In contrast, step-scanning calorimetry can be readily applied to complex, multicomponent systems such as magmas to provide in-situ quantitative measurements of enthalpy across the liquidus-solidus interval. Such measurements provide detailed information on the distribution of latent heat during melting and crystallization that cannot be obtained by conventional drop calorimetry. These data are critical for models describing the thermal evolution of cooling magma bodies.

Acknowledgements This research was supported by the National Science Foundation (grant EAR-9104923). The electron microprobe facility at the University of Oregon was funded by grants from the National Science Foundation (EAR-9204446) and the W.M. Keck Foundation. The electron microprobe facility at the University of Michigan was funded by grant EAR-8212764 from the National Science Foundation.

\section{References}

Berman RG (1988) Internally consistent thermodynamic data for minerals in the system $\mathrm{K}_{2} \mathrm{O}-\mathrm{Na}_{2} \mathrm{O}-\mathrm{CaO}-\mathrm{MgO}-\mathrm{FeO}-\mathrm{Fe}_{2} \mathrm{O}_{3}$ $\mathrm{Al}_{2} \mathrm{O}_{3}-\mathrm{SiO}_{2}-\mathrm{TiO}_{2}-\mathrm{H}_{2} \mathrm{O}-\mathrm{CO}_{2}$. J Petrol 29:445-522

Brandeis G, Jaupart C, Allegre CJ (1984) Nucleation, crystal growth and the thermal regime of cooling magmas. J Geophys Res $89: 10,161-10,177$

Brown, FH (1971) Volcanic petrology of the Toro-Ankole region, western Uganda. $\mathrm{PhD}$ thesis, University of California, Berkeley

Carslaw HS, Jaeger JC (1959) Conduction of heat in solids, 2nd edn. Oxford University Press, Oxford

Cashman KV (1993) Relationship between plagioclase crystallization and cooling rate in basaltic melts. Contrib Mineral Petrol $113: 126-142$

Delaney PT (1988) Fortran 77 programs for conductive cooling of dikes with temperature-dependent thermal properties and heat of crystallization. Comp Geosci 14:181-212

DeYoreo JJ, Lux DR, Guidotti CV (1989) The role of crustal anatexis and magma migration in the thermal evolution of regions of thickened continental crust. In: Daly JS, Cliff RA, Yardley BWD (eds) Evolution of metamorphic belts. Geol Soc London Spec Publ 43:187-202

Ghiorso MS (1991) Temperatures in and around cooling magma bodies. In: Perchuk LL (ed) Progress in metamorphic and magmatic petrology. Cambridge University Press, Cambridge, pp $387-410$
Ghiorso MS, Carmichael ISE (1987) Modeling magmatic systems: petrologic applications. In: Carmichael ISE, Eugster HP (eds) Thermodynamic modeling of geological materials (Reviews in Mineralogy, vol. 17). ch-pp 467-499

Ghiorso MS, Carmichael ISE, Rivers ML, Sack RO (1983) The Gibbs free energy of mixing of natural silicate liquids: an expanded regular solution approximation for the calculation of magmatic intensive variables. Contrib Mineral Petrol 84:107145

Jaeger JC (1959) Temperatures outside a cooling intrusive sheet. Am J Sci 257:44-54

Jaeger JC (1961) The cooling of irregularly shaped igneous bodies. Am J Sci 259:721-734

Kelley KK (1960) Contributions to the data on theoretical metallurgy. XIII. High temperature heat content, heat capacity, and entropy data for the elements and inorganic compounds. US Bur Mines Bull 584

Kilinc A, Carmichael ISE, Rivers ML, Sack RO (1983) The ferricferrous ratio of natural silicate liquids equilibrated in air. Contrib Mineral Petrol 83:136-140

Lange RA, Navrotsky A (1992) Heat capacities of $\mathrm{Fe}_{2} \mathrm{O}_{3}$-bearing silicate liquids. Contrib Mineral Petrol 110:311-320

Lange RA, Carmichael ISE, Stebbins JF (1986) Phase transitions in leucite $\left(\mathrm{KAlSi}_{2} \mathrm{O}_{6}\right)$, orthorhombic $\mathrm{KAlSiO}_{4}$, and their iron analogues $\left(\mathrm{KFeSi}_{2} \mathrm{O}_{6}, \mathrm{KFeSiO}_{4}\right.$ ). Am Mineral 71:937-945

Lange RA, DeYoreo JJ, Navrotsky A (1991) Scanning calorimetric measurement of heat capacity during incongruent melting of diopside. Am Mineral 76:904-912

Larsen ES (1945) Time required for the crystallization of the great batholith of southern and lower California. Am J Sci 243A:399-416

Lovering TS (1936) Heat conduction in dissimilar rocks and the use of thermal models. Geol Soc Am Bull 47:87-100

Richet P, Bottinga Y (1984) Anorthite, andesine, wollastonite, diopside, cordierite and pyrope: thermodynamics of melting, glass transitions, and properties of the amorphous phases. Earth Planet Sci Lett 67:415-432

Richet P, Leclerc F, Benoist L (1993) Melting of forsterite and spinel, with implications for the glass transition of $\mathrm{Mg}_{2} \mathrm{SiO}_{4}$ liquid. Geophys Res Lett 20:1675-1678

Robie RA, Hemingway BS, Fisher JR (1978) Thermodynamic properties of minerals and related substances at $298.15 \mathrm{~K}$ and 1 bar $\left(10^{5}\right.$ pascals $)$ pressure and at high temperatures. US Geol Surv Bull 1452

Spohn T, Hort M, Fisher H (1988) Numerical simulation of the crystallization of multicomponent melts in thin dikes or sills 1 . The liquidus phase. J Geophys Res 93:4880-4894

Stebbins JF, Carmichael ISE (1984) The heat of fusion of fayalite. Am Mineral 69:292-297

Stebbins JF, Carmichael ISE, Weill DE (1983) The high temperature liquid and glass heat contents and the heats of fusion of diopside, albite, sanidine and nepheline. Am Mineral 68:717730

Wickham SM (1987) The segregation and emplacement of granitic magmas. J Geol Soc Lond 144:281-297

Wyllie PJ (1977) Crustal anatexis: an experimental review. Tectonophysics $43: 41-71$ 